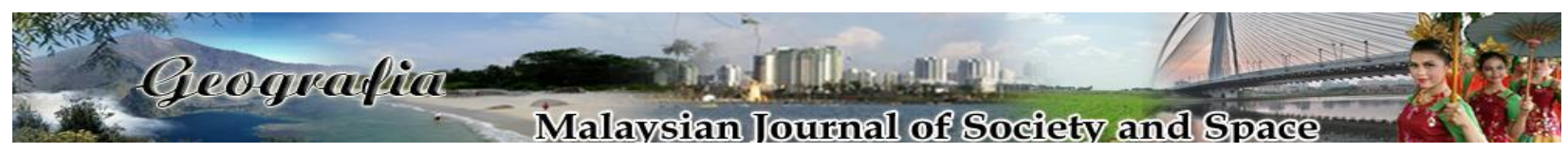

\title{
Balancing majority and minority rights: Lessons from Malaysia
}

\author{
Azeem Fazwan Ahmad Farouk ${ }^{1}$, Azrina Husin ${ }^{2}$ \\ ${ }^{1}$ Centre for Policy Research and International Studies, Universiti Sains Malaysia \\ ${ }^{2}$ School of Social Sciences, Universiti Sains Malaysia
}

Correspondence: Azrina Husin (email: azrina@usm.my)

Received: 01 October 2020; Accepted: 24 November 2020; Published: 29 November 2020

\begin{abstract}
This article seeks to unravel the complex, and often opaque state of ethnic relations in Peninsular Malaysia, a plural society, by focusing on the promotion and protection of minority rights. This country, as few others, is characterized by a very marked ethnic, religious, and cultural diversity, which even a casual observer cannot fail to notice. Ever since independence, the co-existence of these different communities turned out to be very complex and riddled with strong tensions. However, incidents of interethnic violence as well as deadly ethnic riots, were very rare across the national territory. The exception to this claim is the May 13th, 1969 ethnic riots that in turn have become the nation's negative myth - a disruptive conflict that must never occur again. By using a case study approach of historical events, the findings of this article suggest that in order to avoid inter-ethnic violence, a politics of power sharing and affirmative action characterized by permanent negotiations and compromises are the order of the day. Co-existence, however, is still grounded in the social logic of unity in separation. This article seeks to illustrate the workings of the above-mentioned political setting where ethno-cultural and religious diversity are managed so as to ensure minority rights are secured and protected.
\end{abstract}

Keywords: interethnic violence, Malaysia, multiculturalism, plural society, power sharing, unity in diversity

\section{Introduction}

The nature of ethnic relations in Malaysia is a highly contentious subject. This article begins with the premise that the state of ethnic relations in Malaysia can be placed somewhere in between stable existence and crisis. Most western scholars (Furnivall, 1947; Horowitz, 2001) for example, are of the opinion that the sparks that can ignite the flames of ethnic conflict are ever present in the country, and that Malaysia is almost always on the verge of an inevitable ethnic violence. Following this line of argument, a Malaysian expert has observed that the country managed its ethnic conflict through "coercive consociationalism" (Mauzy, 1993, p. 106). What these scholars 
seem to ignore is the fact that in historical terms, "plurality" had colored Southeast Asian societies long before the coming of Europeans. Having said that, this article cautions that in spite of their long-standing contact, spanning a period of more than a hundred years, there had been not much social interactions between the native Malays and the non-Malays. The influx of Chinese and Indian immigrants could well be attributed to the British liberal immigration policy while the British divide and rule strategy had sown the seeds of mistrust among the ethnic groups. Even though ethnic relations in Malaysia is markedly different than that in countries such as Sri Lanka or Rwanda, one of the consequences of the colonial policy of deliberate segregation is to amplify prejudices among its diverse ethnic population. Mohamad Abu Bakar (2001), for example, argues that a colonial policy that was very much undergirded by biological racism of natural differences, had caused the preservation and institutionalisation of perceived differences among the different communities (Mohamad Abu Bakar, 2001, p. 34). This phenomenon is exemplified by the Malay nationalist quest for independence, and later, the formation of ethnic based political parties representing the three major ethnic groups. The politicization of ethnic and religious identities had actually accentuated ethnic awareness among these ethnic groups as well as curtailed inter-ethnic interactions among them.

One of the earliest documented incidents of ethnic conflict in Malaysia took place immediately after World War II in Batu Pahat, Johor, and the most bloody occurred a few days after the general elections that was held in May of 1969. The then Perikatan government reacted to the ethnic violence by introducing an affirmative action policy that aims to eradicate poverty and restructure society. While the final objective of this policy is to achieve inter-ethnic parity and national unity, its implementation was not well received by the Chinese community. They Chinese community felt that the affirmative action policy, officially known as the New Economic Policy (NEP) had the reversed effect of promoting national disunity due to the fact that the actions taken were much in favour of the economically backward and rural based Malay community. The NEP could well be considered as a social engineering project undertaken by the post-colonial state to address economic imbalances brought about by colonial rule.

Even though Malaysia is still grappling with the problem of promoting inter-ethnic harmony, some observers believe that in pure statistical terms, incidences of ethnic violence in Britain, Germany, and France in the last five years far outnumbered the figure in the last 45 years of Malaysian post-independent history (Shamsul, 2005, p. 5). Thus, with regards to Malaysia's ethnic relations, the country has been characterized as one that is sitting "in a state of stable tension" (Shamsul, 2005, p. 5). The Malaysian government had been active in promoting ethnic integration by formulating various state-centered doctrines, the most important being the national ideology known as rukun negara. While there is a lack of systematic research undertaken to evaluate the effectiveness of Malaysia's National Integration Policy programs, it does not change the fact that the state had taken some measures in promoting national unity as well as protecting and ensuring minority rights. Malaysia's second premier, Tun Abdul Razak, for example had strongly advocated for participation in voluntary associations as a means to forge integration among the diverse Malaysian communities (Case, 1993: 189).

In this article, we seek to describe how Malaysia has dealt with diversity and pluralism in the pre-independence period until the present day. We argue that co-existence of the diverse ethnic groups is first and foremost based on the politics of power sharing and affirmative action that are characterized by permanent negotiations and compromises. Nevertheless, coexistence is still grounded in the social logic of unity in separation which may appear rather paradoxical to 
Europeans who cherish the idea that cultural homogeneity is the cornerstone of social cohesion and a guarantee of equal citizenship and/or nationality rights and duties for all.

\section{Plural society in the colonial era: Colonial social and economic engineering}

Plural society is a concept that is developed by John S. Furnivall (1947), a British colonial official famous for his study on the socioeconomic structure of Southeast Asian societies. Even though Furnivall's observations do not refer directly to the situation in the Malay states, his broad brush on plural society is still taken as an authoritative narrative of inter-ethnic ties in Southeast Asia. According to Furnivall, a plural society is characterized by "two or more elements or social orders which live side by side, yet without mingling, in one political unit" (Furnivall, 1944, p. 446). He argues that it is the economic needs or more specifically, the exchange of goods, that bind these different ethnicities who live and share the same territory. In other words, the social relations among these diverse groups are shaped by material needs and is utilitarian in nature. These relations lack a social and/or symbolic ties in which common values are shared among its members, bringing about a shared identity. As a result, as far as social cohesion is concerned, mutual solidarity is weak and quite unpredictable. According to Furnivall:

"The community tends to be organized for production rather than for social life; social demand is selectionalized, and within each section of the community the social demand becomes disorganized and ineffective, so that in each section the members are debarred from leading the full life of citizen in a homogenous community; finally, the reaction against these abnormal conditions, taking in each section the form of nationalism, sets one community against the other so as to emphasize the plural character of the society and aggravate its instability, thereby enhancing the need for it to be held together by some force exerted from outside" (Furnivall, 1944:459).

In the $21^{\text {st }}$ century, Furnivall's perspective can easily be debunked, and as a matter of fact, quite a few scholars have questioned the appropriateness of using the term plural society as a socioanthropological concept. This concept, however, proves to be a good analytical tool in order to understand the reasons underpinning the development of a specific idea of citizenship in Malaysia (and in other countries in Southeast Asia like Singapore and Indonesia). This article will summarize the most legitimate criticisms and then show what application it might still have, with specific reference to Malaysia's peninsular area.

There is no doubt that Furnivall's assessment offers a pessimistic view on the likelihood that plural societies might become socially cohered and politically stable entities like the European nations, organized in conformity with the nation's state model. This comparison, never openly stated, arbitrarily assumes that from an ethnic and/or cultural point of view European societies, contrary to Southeast Asian ones, are homogenous systems. Today, this position seems quite mind boggling considering the fact that when Furnivall wrote his article, Europe was being torn asunder by raging nationalism and racisms that strove to annihilate any other type of otherness within what supposedly had to be utterly pure and uncontaminated nation. Furnivall chose not to see the typically European phenomenon labelled as the gardener state (Bauman, 1991, p. 43) whose function is to physically or otherwise efface minorities that are looked upon at best as a bothersome phenomenon. Another criticism that was levelled against Furnivall was that he disregarded the fact that plural societies including those in Southeast Asia are the upshot of European political 
engineering, a direct outcome of the British and Dutch colonial system which subscribed to the divide et impera principle. This principle provided an effective way of governing as parallel societies were created based on spatial segregation among these ethnic groups, at the same time accentuating ethnic differences rather than similarities. To further legitimize their control is the rhetoric of having to be present in order to avoid the worst from happening in these highly ethnically segregated lands. This ideology of interconnectedness can be discerned in Furnivall as well, despite being very explicit on some ethnic representations perpetuated by the British colonialist. To him, plural societies was in existence prior to the colonizers' arrival. This is not exactly true because colonial power had, as a matter of fact, formulated immigration policies that encouraged large scale migration of the Indians and the Chinese which deeply altered the societies that existed before the arrivals of the Europeans.

Studying the specific situation in British Malaya, Maurice Friedman highlights that the notion of plural society is based more on mental or, better yet, cultural constructions, rather than on evidence of the existence of structural elements; namely the unquestionable presence of separately autonomous, and clearly distinguishable ethnic groups (Vincent, 1996, p. 426). This shows that the social configurations examined by Furnivall is Southeast Asia should not be regarded as unchangeable phenomena that emerged in a distant past. Plural societies and their ethnic aspects are very dynamic realities stemming from recent cultural constructions. Despite legitimate criticisms, we are of the view that the notion proposed by Furnivall is further corroborated by the fact that at independence, a plural society had emerged in what is present day Peninsular Malaysia, set in motion by the British colonial policy. Among the main ethnic groups that migrated to the Malay Peninsular, the Chinese was the biggest. In colonial times as is today, the Chinese community is not a homogenous group, both from a social and a cultural lens. This is evident from the various religions and/or religious beliefs and languages that characterized them. While the factors that pushed them to then-Malaya were different, the Chinese community in this country belongs to these five creeds, namely Buddhis, Taoist, Confucian, Muslim, and Christian. Not only that, they are identified by five to eight linguistic groups. Given these differences, it is incorrect to describe the Chinese community as close knit over the period of $19^{\text {th }}$ century and the first decades of $20^{\text {th }}$ century.

Painting the picture of the Indian community as a homogenous group is incorrect as well. Even though the bulk of immigrants to the Malay Peninsula were Tamils, we should be cognizant of the fact that some were Muslims, as were those who came to the region that is now known as Pakistan. There were also the Punjabi Sikh, who were stationed in Penang, Malacca and Singapore under the British Empire's troops. Also, they were Catholic Indians from Kerala and Goa among this so-called homogenous Indian community, markedly different in the way they had adopted Portuguese surnames.

While some scholars see Islam as a major factor in uniting the Malays in Malaysia, the Malay community is far from being homogenous, and this can be illustrated in two major influences to the community. The first group was a small group of entrepreneurial Arab-Malay traders from Aceh (Northern Sumatra), who were culturally influenced by Yemenite Islam due to their close economic ties with better-known traders and skilled seafarers from the Arabian Peninsula (mainly from the Hadramaut coast). The second group comprised of local Malay who were indigenous to the Malay Archipelago, who subscribe to an eclectic Islam by combining Hindu and animistic practices predating their conversion.

It is worth reiterating that the ties between the different ethnic was mainly purely dictated by

utilitarianism. The period leading up to the end of the $19^{\text {th }}$ century saw the rise in identification to 
a specific ethnic group. For example, in the late $18^{\text {th }}$ century, there was an intense quarrel between Chinese clans from Hokkien province and those from Canton. These clashes brought about violent conflicts between the two groups that disrupted the peaceful coexistence among the different communities in commercial centers such George Town in Pulau Pinang, and had caused problems to the British colonialist. The plain truth is that during these violent clashes between the Chinese clans, the Acehnese businessmen continuously sided with the Hokkien entrepreneurs simply because the two groups shared a vibrant commercial relations that guaranteed steady dealings between Arabia and China - the important life line for this small Malay community's economic well-being. Linguistic, religious, and overall cultural differences were certainly not unimportant but were strategize to avoid direct conflict. That being the case, the Buddhist-Taoist Chinese from Hokkien had no issue on cooperating with Muslims from Aceh to attack the much hated and Buddhist-Taoist-Confucian from Canton, who retaliated with considerable violence.

In the case of Penang, being part of the British colonial empire since 1786, its society had been segregated according to the various ethnic groups, achieved via the British policy of divide et impera. The diverse communities of this island were divided and reduced into three large ethnic groups, namely the Malays, Chinese and Indians, just like in other parts of Peninsular Malaya that were under the British rule. This ethnic reduction was done on a very Eurocentric and arbitrary way in order to identify which communities made up the local social fabric. In addition to this policy of segregation, each community maintained its own territory, creating an ethnically distinct space. This territory was managed by a kapitan, who could be of Chinese, Malay or Indian origin, depending largely on the ethnic population in the territory under his care. Yet, despite being from the same ethic group under his control and had an unmatched level of familiarity on the situation in his territory, he represented the Crown, acting as a liaison officer between the colonial government and his own community. This classification was indeed problematic as it did not take the marked differences within the community into consideration.

The Chinese in Penang, like in other parts of the Malay Peninsular, lived in their specific districts, congregating in town centers to cater to their line of work that revolved largely around commerce. According to historical sources of George Town, the Chinese districts can be identified with that specific community's origin in the mainland as well as the jobs the community were involved in. The Cantonese, for example, were known as goldsmiths, barbers, carpenters and construction hands. The Hokkiens, on the other hand, were known to be in the boat and shipbuilding business as well as fish commerce. They were also known to be in the food and catering business along with the Hainanese and the Hokchiu. The Teochews and Hakka were farmers while the Hakka was also credited as the sole owners of pawnshops. In what is known as Chinatown, each group lived clustered around the shrine of each clan, whose acolytes shared the same religious belief and originated from the same place in the mainland and was identified by the same surname.

As for the Indian community, although they were well known to provide their labours in the rubber plantations away from the city, those who lived in cities like George Town also stayed within their own district, dabbling in cloth and spice retail. Those who belonged to the Islam faith lived close to the mosques while those of the Hinduism faith lived near their temples. As for the Malays, while there were a small number of merchants among them, the rest of the population remained excluded from the city dwellings, safely tucked in the traditional villages toiling their small-scale land and engaging in self-sustaining economic activities.

Malaysia's socioeconomic and cultural traits are similar to an ideal-type plural society. This ideal type is typically exemplify by the following traits : a geographical segregation among the 
ethnic groups, each with its own norms, values, and facilities, further division into ethnic enclaves, an ethnic based division of labor that is more often than not correlated to social inequality among individuals. In the pre-independence Malay states, there was also a strong correlation between ethnic identity, social status and economic standing. These socioeconomic inequalities had reinforced by class differences that could be found within each community. The end of the Second World War witnessed the movement towards decolonization by the major Western powers. This was led by the British, and one if its repercussions in the Malay states was the rise of hyper-ethnonationalization among the various communities. That the Malays, Indians, and the Chinese communities were ethnically conscious was mainly attributable to the process of the British colonial divide-and-rule strategy. Put in another way, the movement towards shaping a community with a distinctly ethnic trait was the result of three factors. First, and perhaps most important was the social and political engineering of British colonial rule. The colonialist had purposely aimed at encouraging and promoting the ethnicization of the different communities in the Malay states. What is more, these identities had become increasingly ethnicized under the tutelage of British colonialism and had slowly taken on a territorial characteristic more so at the district level. Secondly, the direct or indirect influence of nationalist movements that took place in the beginning of the $20^{\text {th }}$ century, especially in China had contributed to the awakening of ethnic consciousness in the Chinese community in the Malay States, more so in the Straits Settlement. Finally, the corresponding and nearly simultaneous rise of nationalism of the other groups (Malays and Indians) had started in the mid-nineteenth century by their respective political and intellectual elites, mainly among those educated in Britain. The rise of ethnic consciousness in the Chinese community cannot be understood without taking into account the construction of the concepts of bangsa and kebangsaan Melayu. The former means race in a narrow sense. The latter refers Malay nationality with a more inclusive sense taking into account the assimilation, and, from a legal stand point the naturalization of the other.

Bangsa and Kebangsaan Melayu meant first and foremost being a Muslim and speaking the Malay language. Sharing similar cultural traits is also an essential part of being a Malay. The process of self-identification, more so towards the end of the colonial period, clearly reveal one community's apprehension of another community's dominance. Most of all, the above-mentioned processes had contributed to the making of a Malay majority and the making of Chinese and Indian minorities. As the decolonizing process was becoming more apparent, one could also witness a parallel rise in ethnic consciousness among the three major ethnic groups on which present-day Malaysia is based.

\section{Balancing majority and minority rights}

When the British colonizers granted Malaya its independence, the political elites had to forge a nation in a highly fractured society in which ethnicity had permeated into all dimensions of economic, social, and political relations. The above rendition highlights the problems that surfaced in Southeast Asia during the shift from a plural society to a new nation-state. Face with an ethnic plurality that is also separated along spatial line, social relations were naturally undermined by reciprocal mistrust. That being the case, the political elites of new nations such as Malaysia and Singapore had to come up with different models of citizenship that would take into account a complex reality in which society, economy, and ethnicity are closely intermingle. Broadly 
speaking, these two nation-states had to create a model of citizenship based on the myth of multiculturalism.

In August of 1957, Britain granted independence to the Malay states and the two Straits Settlements of Penang and Melaka. The setting up of independent Malaya as a post-colonial experiment had proven to be problematic even at the very outset. Ethnic diversity had proven to be an Achilles heel for the newly independent state. Put differently, coming up with a workable model of a nation-state was definitely a daunting task for the political elites. Two inherently contradictory concepts were mooted: a Malay Malaysia and a Malaysian Malaysia strongly espoused by the former Prime Minister of Singapore Lee Kuan Yew. The first model stood for a euro-centric blood nationalism, with the Malays as the entitled nation in which the other groups were allotted, at best the role of national minorities. Within the framework of Malay Malaysia, the question was raised whether it was appropriate to grant citizenship to Chinese, Indian, and other immigrants or native groups. According to this conception, only Malays would have the right to citizenship. Right from the very outset, the precarious nature of the non-Malay's position in the country was highlighted in such a way that the concept of civic nationalism would be in tension with the way in which nationality and citizenship was made implicit in the concept of Malay Malaysia.

The concept of Malaysian Malaysia is in line with civic nationalism conception of a nationstate. Unlike the euro-centric blood nationalism, Malaysian Malaysia essentially means that the nation and state is not identified with the supremacy of any particular ethnic group. This model is much more workable for Malaysia's multi-ethnic society as it acknowledges that all ethnic groups on the federation's territory as members of the community with equal rights. After fierce debates, a hybrid conception of Malaysian Malaysia model based on the founding myth of multiculturalism and/or multiracialism was finally agreed upon. Without doubt, ethnic and/or racial plurality is most explicitly spelled out in this model. One may ask the following question - which interethnic negotiations is the latter version based on?

The post-independent Malaysian constitution represents an ideal-type of a core consociative-like identity negotiations that had created an ethnically divided citizenship based on an explicit differentiation between the indigenous Malays (bumiputera) and immigrants - the nonMalays (non-bumiputera). There was a tacit understanding that the backwardness of Malay community socioeconomic development had to be addressed. In order to correct the socioeconomic imbalance among the diverse ethnic groups, it was agreed that special provisions concerning economy, education, and property rights (especially on land) were given to the Malays and other indigenous groups collectively known as the bumiputera. The Malaysian constitution clearly spelt out that land that should be reserved for bumuputera, and has provisions regarding business licenses and concessions, quotas in higher education and civil service (see article 89, 152, 153 of the Malaysian constitution) that are dedicated to the bumiputera. Non-Malays were granted full-citizenship, as well rights of religious and linguistic expression in a secular state where Islam is the state religion. This institutional compromise is the outcome of defensive strategies ascribable to reciprocal fears and apprehension that Malaysian society's different ethnic communities. What are the fears that troubled the different communities? Being the bumiputera (sons of soil), the Malays feared the non-Malays, particularly the Chinese, socioeconomic prowess and that they (the Malay) would suffer the same plight as the native Americans whereas the non-Malays worried about the future of their economic well-being and their cultural identity in a state with a strong Islamic identity. 
What is more, despite the constitutional settlement, public life goes on respecting ethnicboundaries, and referent to the social contract notwithstanding, the non-Malays accepted albeit grudgingly, the political dominance of the Malay community in exchange for their own economic supremacy. This arrangement is referred to by Arend Lijphart as the existence of hegemonic consociationalism in Malaysia (Lijphart, 1977, p.5). However, we should consider this asymmetry as far from complete; if not, it would be misleading to speak of consociationalism. In line with this political arrangement, the federal government has always been a coalition of ethnic parties, giving rise ever since independence in 1957 to the Barisan Nasional (National Front), whose main political raison d' etre has been the nearly compulsive pursuit of a spirit of consensus that is often difficult to achieve. However, the institution of a constitutional head selected by rotation among the nine Malay monarchs symbolically endorses the Malay community's political predominance over the other, since becoming king (Yang Dipertuan Agong) is the exclusive prerogative of the sultans of the nine states (out of thirteen) in the federation. A strict rotation system defined in the constitution governs the accession to this purely representative office of the Head of State.

After independence, the bargain or the social contract that was embedded in the constitution has proven to be troublesome, and on quite a number of occasions, new negotiated settlements have altered the nature of Malaysia's ethnically divided citizenship. Despite the differences and permanent tensions among the ethnic groups, the camaraderie among the political elites had ensure that a consensual solution was reached. As mentioned at the outset, after the May $13^{\text {th }} 1969$ ethnic riots, the New Economic Policy (NEP) was launched granting crucial social and economic rights to the Malays, whose socioeconomic situation had worsened compared to the middle and higher income groups that were made up of non-Malays, even after twelve years of independence. To avoid any further similar incidents, as well as possible flight of the wealthier Chinese along with their capitals, the government loosened some provisions of the affirmative action, thanks to a series of positive discrimination policies under the NEP for the Malays which is still in force, and which is accepted by the non-Malays even if unwillingly.

The 1990s witnessed a period of high economic growth in Malaysia. What is more, the growth in per capita income had not only lessened income inequality among the different ethnic groups but promote better ethnic relations as well. Using the feel good factor that was hovering over Malaysia at that point in time, the former Prime Minister Mahathir Mohamad launched his Vision 2020 nation building project. The main gist of the Vision 2020 is to create a bangsa Malaysia - a civic nationalism type nation-state building project that is inclusive of all citizens irrespective of ethnicity. Under the $6^{\text {th }}$ Prime Minister Najib Razak, this project was replaced by 1Malaysia. Just like the civic nationalism type nation-state building project, 1Malaysia aims to bring about norms and values that will sow the seed for the growth of a "tolerant" society in which Malaysians of all ethnic backgrounds will be free to practice and profess their customs, cultures, and religious beliefs, and yet feel that they belong to one nation. In reality, this means that even in the foreseeable future, Malaysia will continue be a multi-ethnic state based on a consensual segregation along ethnic lines. In order to bring about inclusivity the citizenship model will be expanded through the concept of Bangsa Malaysia and 1Malaysia. Both of these concepts aim to create single civic body that will transcend ethnicity. Finally, in order to create "unity in diversity" both Vision 2020 and 1Malaysia had attempted to introduce a less ethnic and more meritocratic idea of citizenship. From this perspective, Malaysia seems to follow Singapore's nation-state building template. It is a well-known fact that Singapore's nation-state building project was largely based on the combination of two myths: multiracialism and meritocracy. 


\section{Conclusion: Political change and continuity}

We need to understand that the entire ethnic policy characterized by permanent negotiations and accommodations among the different ethnic groups' representatives is grounded on the principle of national unity. One of the tools that is used in achieving a civic body that transcends ethnicity is the ideological doctrine known as rukun negara. This is where the basic idea of unity in diversity is asserted: "though ethnically different we are all Malaysians - we are all Malaysians precisely because we can all maintain our ethnic, cultural, and religious diversity". The Rukun Negara doctrine, which proved to be very effective both as a weapon of legitimation for current political elite affiliated to the Barisan Nasional for the past 60 years and as the foundation of national cohesion, is the ideological basis of that veritable cult of identity diversity without territorial boundaries. The political question that arises is what claims of minority groups should be politically recognized, and why? All modern democratic societies contain multiple cultures within them. This is in straightforward sense how democratic societies can be called multicultural. Some minority groups in a democratic society must compete with the dominant group to provide a context of choice for their members and therefore find themselves at a disadvantage. In Malaysia, the state protects the rights and culture of the dominant group through the language it uses, the education it accredits, and the history it honors. Nevertheless, as mentioned above, the constitution provides protection for cultural and linguistic rights for the minorities. This is the context in which the minority rights are protected and in which minority groups make claims upon the state.

In the wake of Pakatan Harapan's (PH) collapse in February 2020, political elites face the daunting task of drawing lessons from an ad hoc alliance between incompatible political parties and are now adjusting to the new political reality. It just goes to show that Malaysia's polarizing divide remains dominant and seem entrenched. Nevertheless, a power sharing arrangement between the majority and minority ethnic groups in the country is still the working formula that is chosen by political parties. This formula has proven that an equilibrium between the majority and minority ethnic groups in the country is achievable.

\section{References}

Bauman, Z. (1991). Modernity and ambivalence. Ithaca, Cornell University Press.

Brubaker, R. (2015). Ethnicity without groups. New Community, 23(1), 123-31.

Case, W. (1993). Semi-Democracy in Malaysia: Withstanding the pressures for regime change. Pacific Affairs, 66(2), 183-205.

Despres, L.A. (Ed.) (1975). Ethnicity and resource competition in plural societies. Chicago, Mouton.

Federal Constitution of Malaysia (2017). National Printing Press of Malaysia.

Furnivall, J. S. (1944). Netherland's India: A study of plural economy. (2 ${ }^{\text {nd }}$ ed.). Cambridge, Cambridge University Press.

Gomez, E.T. (1999). Chinese business in Malaysia: Accumulation, ascendance, accommodation. Honolulu, University of Hawaii Press.

Gurr, T.D. (1992). Minorities at risk: A global view of ethnopolitical conflicts. Washington DC, Institute of Peace Press.

Horowitz, D. (2001). The deadly ethnic riot, Berkeley, University of California Press.

Keyes, C.F. (Ed.). (1981). Ethnic change. Seattle, University of Washington Press. 
Lijphart, A. (1977) Democracy in plural societies: A comparative exploration. New Haven, Yale University Press.

Mohamad Abu Bakar. (2001). Islam, civil society and ethnic relations in Malaysia. In Nakamura

M., Siddique S. \& Bajunid, O.F. (Eds.), Islam \& civil society in Southeast Asia (221-235). Singapore, Institute of Southeast Asian Studies.

Mauzy, D.K. (1993). Barisan Nasional: Coalition government in Malaysia. Kuala Lumpur, Mericans.

O’Leary, D. (1993). Asian style democracy, Asian Survey, 34(11). 949-61.

Shamsul, A.B. (2005). The construction and management of pluralism: Sharing the Malaysian experience. ICIP Journal, 2(1), 1-14.

Vincent, J. (1996). Plural Society. In. Alan, B. \& Jonathan, S. (Eds.), Encyclopedia of social and cultural anthropology (145-56). London, New York, Routledge. 